\title{
Interaction between invasive and potentially invasive shrub species does not influence relationships between their ecological success and distance from propagule sources
}

\author{
Marcin K. Dyderski · Piotr Banaszczak • Mateusz Rawlik • Andrzej M. Jagodziński
}

Received: 6 January 2017 / Accepted: 23 May 2017/Published online: 31 May 2017

(C) The Author(s) 2017. This article is an open access publication

\begin{abstract}
Although interactions between alien and native plant species are well studied, data on interactions between two co-existing alien species with respect to their invasibility are scarce. The aims of this study were (1) to evaluate three factors shaping abundance of the alien shrub species Cornus alternifolia: abundance of another alien (invasive) shrub species (Prunus serotina), type of tree stand (coniferous vs. broadleaved) and distance to propagule sources and (2) to assess the potential dispersal distance of the species studied. Densities of both species were assessed within 194 experimental plots (located in experimental plantations of trees) in Rogów Arboretum (Central Poland). P. serotina occurred on 79 and C. alternifolia on 33 of the 194 plots. The furthest distance of $C$. alternifolia from the propagule source was $338 \mathrm{~m}$. C. alternifolia reached higher densities in
\end{abstract}

Communicated by Lori Biederman.

Electronic supplementary material The online version of this article (doi:10.1007/s11258-017-0740-z) contains supplementary material, which is available to authorized users.

M. K. Dyderski · A. M. Jagodziński ( $\)$

Institute of Dendrology, Polish Academy of Sciences,

Parkowa 5, 62-035 Kórnik, Poland

e-mail: amj@man.poznan.pl

M. K. Dyderski · A. M. Jagodziński

Department of Game Management and Forest Protection,

Poznań University of Life Sciences, Wojska Polskiego

71c, 60-625 Poznan, Poland coniferous than broadleaved tree stands. Density of $C$. alternifolia depended on tree stand type and distance from the propagule source, but did not depend on density of $P$. serotina. Density of $C$. alternifolia decreased with increasing distance from the propagule source; however, this relationship was modified by the type of tree stand: densities were lower in broadleaved than in coniferous stands. The presence of the invasive species seems to neither facilitate nor limit the dispersal distance of $C$. alternifolia, as these two species differ in shade tolerance. The study also provided the first information about $C$. alternifolia potential invasiveness, because earlier this species was noticed only as casually escaping from cultivation in Slovakia.

Keywords Secondary invasion - Prunus serotina . Cornus alternifolia $\cdot$ Shade tolerance $\cdot$ Dispersal distance $\cdot$ Spread

\footnotetext{
P. Banaszczak

Warsaw University of Life Sciences, Forest Experimental Station in Rogów, Rogów Arboretum, Akademicka 20, 95-063 Rogów, Poland

M. Rawlik

Department of Plant Ecology and Environmental Protection, Faculty of Biology, Adam Mickiewicz University, Umultowska 89, 61-614 Poznan, Poland
} 


\section{Introduction}

Invasive species cause harmful consequences for biodiversity conservation and difficulties for management. Due to the longevity and size of woody species (Richardson and Rejmánek 2011; Rejmánek 2014), as well as their strong ability to modify habitat (transformers species sensu Richardson et al. 2000), invasive woody species can be especially damaging to the environment. Tree species (both alien and native) influence light availability (Knight et al. 2008; Niinemets 2010), mineral nutrient cycling (Augusto et al. 2002; Reich et al. 2005; Dauer et al. 2007; Mueller et al. 2012), soil acidity (Binkley and Valentine 1991; Binkley and Giardina 1998; Mueller et al. 2012), decomposition rate (Hobbie et al. 2006, 2007, 2010), fine root and leaf lifespans (Withington et al. 2006), ectomycorrhizal infections (Dickie et al. 2006; Trocha et al. 2012), and soil biota (Mueller et al. 2015, 2016). Modifying effects of invasive woody species on habitat was also reported from several biomes across the world (e.g., Vitousek 1990; Ehrenfeld 2003; Stohlgren and Rejmánek 2014; Castro-Díez et al. 2014; Menge and Chazdon 2016). Among woody species, some guilds are especially responsible for ecosystem change, e.g., nitrogenfixing species (e.g., Ehrenfeld 2003; Rice et al. 2004; Castro-Díez et al. 2014; Jo et al. 2015) or coniferous trees planted on sites typical to broadleaved trees (e.g., Binkley and Valentine 1991; Augusto et al. 2002; Zerbe and Wirth 2006; Jagodziński et al. 2015).

Habitat invasibility depends on propagule pressure (Lonsdale 1999; Lockwood et al. 2005; Křivánek et al. 2006). This term describes availability of propagules, for example expressed as quantity of mature plants (Vanhellemont et al. 2009), cultivation intensity (Pyšek et al. 2009, 2015), distance to the nearest fruiting plant (Jagodziński et al. 2015), or propagule quality (Sinclair and Arnott 2015). Probability of occurrence and density of natural regeneration decreases with distance from the seed source (Riepšas and Straigyté 2008; Deckers et al. 2005; Terwei et al. 2013; Jagodziński et al. 2015). Propagule pressure is also connected with the presence of dispersal agents, in the case of species producing edible fruits, with presence of frugivorous birds. Behavior of dispersal agents may influence spread of some species-for example presence of coniferous tree stands as places for perching and defecation (Źywiec et al. 2013).
Accurate assessment of maximum dispersal distance is necessary for proper placement of species invasiveness within a naturalization-invasion continuum (Richardson and Pyšek 2006).

One of the most important consequences is higher competitive performance of alien species, which displace native species (Vitousek 1990; Lövei 1997; Rejmánek 2014). There are many studies concerning competition between alien and native plant species (Gorchov and Trisel 2003; Saccone et al. 2010; Robakowski and Bielinis 2011; Kawaletz et al. 2014; Sanderson and Antunes 2013; McShane et al. 2015). On the other hand, Davis (2003) argued that competition from introduced species is not an important cause of native species extinctions. However, in studies concerning relationships between invasive and native species, authors frequently focused only on competition between the alien and native species, and intraspecific competition, neglecting relationships between two invaders (e.g., Mangla et al. 2011; Rodríguez-Echeverría et al. 2013). Studies concerning relationships between two alien species are relatively rare, but essential to better understanding the competitive interactions among alien species, and increase our knowledge of secondary invasions (Gioria and Osborne 2014). It is especially important when occurrence of earlier-established invaders modifies environments in ways which facilitate dispersal distance of secondary alien species, according to the invasional meltdown concept (Simberloff and Von Holle 1999; Simberloff 2006; Gioria et al. 2011). In one case of herbaceous invasions, there is evidence of higher competitive ability of the secondary invader Fallopia japonica, over the primary invader Gunnea tinctoria, which was displaced by $F$. japonica over a few years (Gioria et al. 2011). In cases of competition between two invaders, higher morphological plasticity is one of the reasons for superior competitive ability of one species (Mony et al. 2007).

The aim of this study was to assess the performance of the alien shrub Cornus alternifolia. We investigated interactions among three factors: effects of plantations of ecologically alien (coniferous) tree species, competition with invasive shrub (Prunus serotina), and distance from propagule source. We hypothesized that the relationship between density of $C$. alternifolia and distance from the propagule source will be modified by density of $P$. serotina and by the type of the tree stand, which reflects habitat modification by forest 
management. Our secondary aim was to evaluate the maximum dispersal distance of $C$. alternifolia to assess its potential invasiveness.

\section{Materials and methods}

Species studied

Cornus alternifolia $\mathrm{L}$. $\mathrm{f}$. is a member of the Cornaceae family with a natural range in eastern North America. Cornus alternifolia is a small tree, reaching heights up to $9 \mathrm{~m}$. Within its native range $C$. alternifolia, due to its shade tolerance, occurs in the understory of several types of forests, both deciduous (especially with Acer rubrum, but also with Betula alleghaniensis, Ulmus americana, Fraxinus spp., Populus spp., and Quercus spp.) as well as mixed and coniferous (usually with Abies balsamea, Picea rubens and Pinus taeda) most frequently on well-drained deep soils. Usually $C$. alternifolia co-occurs with Prunus serotina. This species can reproduce by root suckers and seeds, which are dispersed by gravity and animals (Coladonato 1994). Wide geographical and climatic range, together with its ornamental value, allows $C$. alternifolia to be cultivated in several countries, which can favor risk of invasion (Pyšek et al. 2009; Rejmánek 2014). However, this species was never found escaping from cultivation, except in Slovakia (Medvecká et al. 2012), where it was treated as casual and not invasive in natural ecosystems.

Prunus serotina Ehrh. is a tree in the Rosaceae family from eastern North America. P. serotina occurs mainly in deciduous and mixed forests with Acer rubrum and $A$. saccharum, Betula alleghaniensis, $B$. lenta, Carya spp., Picea spp., Pinus taeda, P. strobus and other Pinus spp., Populus spp., and Quercus spp. (Burns and Honkala 1990). This species was introduced into Europe as an ornamental shrub and for production of high quality timber. When timber production failed, it was widely planted to improve soil quality. It most frequently has a shrub form, in contrast to its native range, where it grows into a tall tree able to produce valuable timber (Burns and Honkala 1990; Starfinger et al. 2003; Halarewicz and Żołnierz 2014). Prunus serotina is one of the most widespread invasive woody species in Europe, especially in coniferous forests (e.g., Chabrerie et al. 2008;
Knight et al. 2008; Vanhellemont et al. 2009; Jagodziński et al. 2015).

Area of the study

Rogów Arboretum $\left(51^{\circ} 49^{\prime} \mathrm{N}, 19^{\circ} 53^{\prime} \mathrm{E} ; 189 \mathrm{~m}\right.$ a.s.l.) is the Forest Experimental Station of Warsaw University of Life Sciences (SGGW) with collections of ornamental woody plants and experimental forestry stands of 75 species of trees (Jagodziński et al. 2015). Within the Rogów Arboretum, all plots are located in potential habitat of fertile deciduous forest (potential natural vegetation is Tilio-Carpinetum, a subcontinental oak-lime-hornbeam forest). Soil parental material in the arboretum is homogenous. In the study area, there are gray-brown podzolic forest soils with horizons O-A-Eet-Bt-C (Czępińska-Kamińska et al. 1991; Jagodziński and Banaszczak 2010). Nevertheless, plantation of ecologically and geographically alien, usually coniferous species (Jagodziński et al. 2015), has led to increased litterfall of acidic needles, decreased soil pH, leaching of soil nutrients (e.g., Binkley and Valentine 1991; Augusto et al. 2002) and increased light availability (Knight et al. 2008). The nearest meteorological station in Strzelno (covering the last 55 years) had a mean annual temperature of $7.2{ }^{\circ} \mathrm{C}$ (mean January temperature was $-3.2{ }^{\circ} \mathrm{C}$ and mean July temperature was $17.3{ }^{\circ} \mathrm{C}$ ), mean annual precipitation of $596 \mathrm{~mm}$, and mean growing season length of 212 days (Jagodziński and Banaszczak 2010).

The original and unique propagule source of Prunus serotina in Rogów Arboretum is a tree stand planted in 1932 in one plot in the central part of the arboretum that had 63 mature trees in 2012 (Jagodziński et al. 2015; Fig. 1). From this one stand (0.14 ha), P. serotina dispersed through the arboretum and beyond. This process was clearly visible because this species has not been planted in the surrounding neighborhood (within $500 \mathrm{~m}$ ) of the arboretum. Cornus alternifolia was planted in three plots. The primary propagule source of $C$. alternifolia was a 0.07 ha tree stand of Acer saccharum and Castanea sativa, where C. alternifolia was planted in 1973. In 2012, 747 C. alternifolia shrubs were present within this plot, including 583 up to $0.5 \mathrm{~m}$, and 164 over $0.5 \mathrm{~m}$ height. This species was also planted in 1976 (four plants) and in 1977 (three plants) in two different 


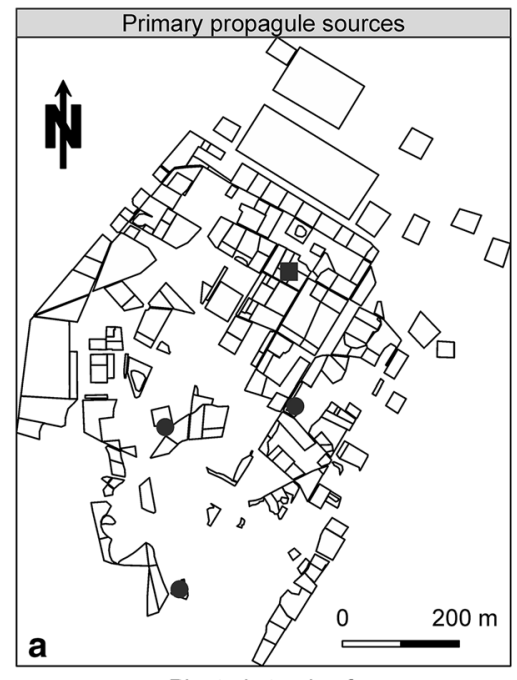

Planted stands of

Cornus alternifolia
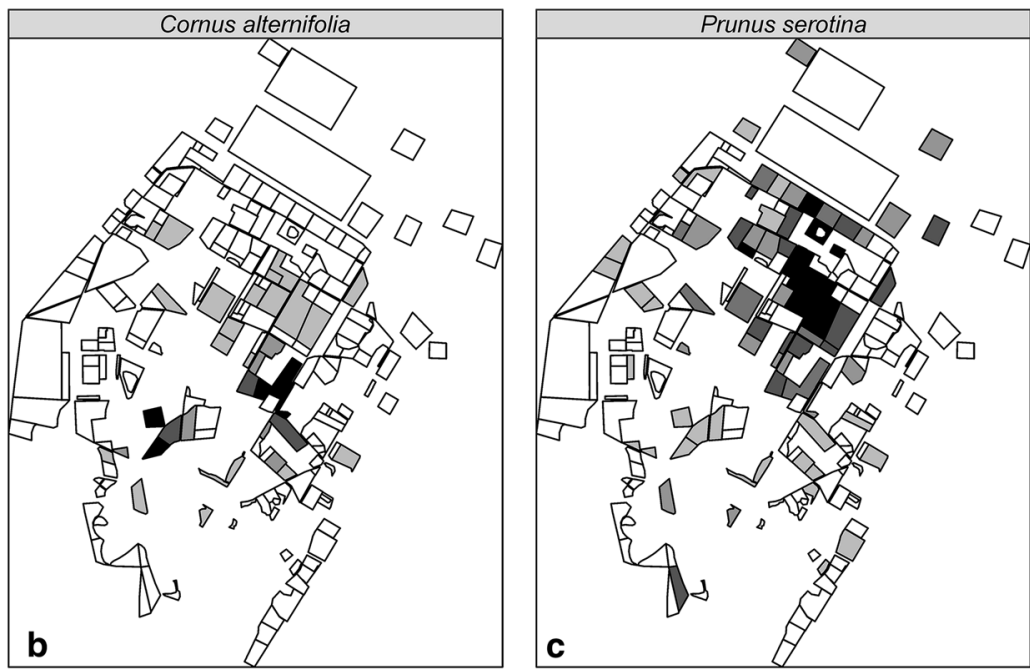

Studied species densities [ind. ha $^{-1}$ ]

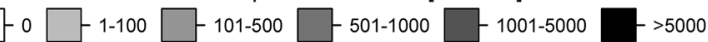

Fig. 1 Study plots in Rogów Arboretum: a localities of first introduction of Prunus serotina (square) and Cornus alternifolia (circles); $\mathbf{b}$ and $\mathbf{c}$ densities of both species studied

stands, located c.a. $300 \mathrm{~m}$ from each other, but not within study plots (Fig. 1).

Both species studied were introduced at different times and with different numbers of seedlings, which resulted in different propagule pressures; thus, one may be concerned that this influenced the results and their interpretation. However, due to the high number of cultivated taxa, providing a wide range of modifications of environmental conditions by alien tree species, historical documentation and homogenous soil conditions, Rogów Arboretum is a very good place to study alien species of trees. Previous studies have examined the dispersal distance of alien species (Jagodziński et al. 2015) and how they drive species diversity of plants, fungi, and invertebrates (Jagodziński et al. 2011; Kasprowicz et al. 2011; Skorupski et al. 2011; Wojterska et al. 2012; Kałucka et al. 2013).

\section{Methods}

During the study in September 2012, we assessed the density of both $C$. alternifolia and P. serotina within 194 plots, all of which were experimental stands of 110 tree species (Online Resource 1). Of these 194 plots, 95 were plots with coniferous tree species, 53 with broadleaved species, and 46 were mixed tree stands. The total area studied was 25.2 ha, with an average plot size of $0.13 \pm 0.02$ ha (minimum plot size: 0.01 ha; maximum plot size: 2.1 ha). Plot sizes differed, as experimental stands have been established over time since the 1920s, and during establishment of the arboretum, it had not been considered as a site for studies on dispersal distance of alien species. Plot sizes and localities were obtained from Arboretum land survey documentation. We excluded from the study plots where the understory was mowed, as well as those with single trees and shrubs and ornamental collections. The density of both $C$. alternifolia and $P$. serotina was calculated in two height classes: low shrubs (i.e., plants up to $0.5 \mathrm{~m}$ height) and tall shrubs (over $0.5 \mathrm{~m}$ ). This division was applied after Jagodziński et al. (2015), where plants lower than $0.5 \mathrm{~m}$ performed differently than tall shrubs.

We examined whether density of $C$. alternifolia depends on dispersal limitation, competition with $P$. serotina and tree stand type. Dispersal limitation was described by distance to the nearest seed source, which was assumed to be one of the localities of introduction mentioned above, because only at those locations has fruiting and seed dispersal been observed and maintained for a relatively long time. Competition with $P$. serotina was measured by its abundance (density) on each plot. Habitat type, due to high variability of tree species planted in the arboretum, was described by tree stand type (broadleaved, coniferous, or mixed tree stand). Due to non-normal distributions, uneven 
variance and high number of zero values, nonparametric Kruskal-Wallis tests were performed to check significance of differences in mean density of $C$. alternifolia between coniferous and broadleaved stands. Mixed tree stands were excluded from further analysis due to lack of $C$. alternifolia. We also assessed the influence of all these factors using generalized linear models based on the negative binomial distribution, as this approach is less biased than traditional linear models computed from logtransformed variables (O'Hara and Kotze 2010) and can overcome problems with long-tailed distributions. We tested models with all combinations of the three factors studied, both additive and interaction variants for low shrubs, for tall shrubs and for the overall density (low + tall shrubs). The best fitted model was chosen based on Akaike's Information Criterion (AIC). All analyses were performed in R software ( $R$ Core Team 2015), and the negative binomial model was performed using the $g \operatorname{lm} . n b$ () function from the MASS package (Venables and Ripley 2002).

\section{Results}

Cornus alternifolia occurred in 33 of 194 experimental plots, including 27 of 95 coniferous tree stands and six of 53 broadleaved tree stands (Table 1). Cornus alternifolia was not found in mixed tree stands. In total, 4330 individuals of $C$. alternifolia were counted, of which $78.3 \%$ were low shrubs and
21.7\% were tall shrubs. The highest densities were found in a stand of Acer saccharum and Castanea sativa, which was the place of first introduction $\left(12,450.0\right.$ ind. $\left.\mathrm{ha}^{-1}\right)$, Carya laciniosa (9140.0 ind. $\mathrm{ha}^{-1} ; 16 \mathrm{~m}$ from the propagule source), Abies koreana (5813.3 ind. ha ${ }^{-1} ; 19 \mathrm{~m}$ ), and two stands of Abies cephalonica $\times$ nordmanniana (5166.7 and 2225.0 ind. $\mathrm{ha}^{-1}$, and 17 and $47 \mathrm{~m}$ from the propagule source, respectively). The furthest distance from the seed source at which $C$. alternifolia was found and was the stand of Abies alba at $338 \mathrm{~m}$, and its density in this plot was 16.7 ind. ha $^{-1}$.

Density of $C$. alternifolia was statistically significantly higher in coniferous than in broadleaved tree stands $(P<0.05$; Table 1$)$. Although mean densities were higher in broadleaved tree stands, medians were equal in both types of tree stands ( 0 ind. ha $\left.{ }^{-1}\right)$, and the 3 rd quartile was higher in coniferous tree stands $(0$ ind. $\mathrm{ha}^{-1}$ in broadleaved tree stands and 9 ind. $\mathrm{ha}^{-1}$ in coniferous tree stands).

Overall density of $C$. alternifolia was explained by the model with four factors: distance from the propagule source, type of tree stand, P. serotina density, and interaction between these last two factors (Table 2). All factors except $P$. serotina density were statistically significant $(P<0.001)$. Density of $C$. alternifolia low shrubs was explained by the same parameters. The density of tall shrubs was best explained by a simpler model, including only distance from the propagule source and $P$. serotina density; however, effects of these covariates were low.

Table 1 Occurrence and density of height classes of Cornus alternifolia in the Rogów Arboretum experimental plots $(n=194)$ within coniferous and broadleaved tree stands

\begin{tabular}{llll}
\hline Features & Overall & Low shrubs $(<0.5 \mathrm{~m}$ height $)$ & Tall shrubs $(>0.5 \mathrm{~m}$ height $)$ \\
\hline Number of plots with $C$. alternifolia & 33 & 31 & 19 \\
Mean density [ind. ha ${ }^{-1}$ ] & 210.1 & 168.2 & 41.9 \\
SE & 89.9 & 73.0 & 19.0 \\
Max density [ind. ha ${ }^{-1}$ ] & $12,450.0$ & 9716.7 & 2733.3 \\
Mean density [ind. ha ${ }^{-1}$ ] in & & & $33.6^{\mathrm{a}}$ \\
Coniferous stands $_{\text {SE }}$ & $198.5^{\mathrm{a}}$ & $164.8^{\mathrm{a}}$ & 15.3 \\
$\quad$ Broadleaved stands & 87.7 & 80.4 & $89.7^{\mathrm{a}}$ \\
SE & $398.4^{\mathrm{b}}$ & $308.7^{\mathrm{b}}$ & 61.6 \\
$P$ & 278.2 & 216.6 & 0.1675 \\
$\chi^{2}$ & 0.0186 & 0.0115 & 1.9049 \\
\hline
\end{tabular}

Values (mean $\pm \mathrm{SE}$ ) with the same letter within rows are not statistically different, according to Kruskal-Wallis tests 
Table 2 Results of generalized linear models (GLM) with negative binomial distributions explaining relationships between density of Cornus alternifolia, distance (from the propagule source), tree stand type (coniferous or broadleaved), and Prunus serotina density

\begin{tabular}{|c|c|c|c|c|}
\hline Variable & Estimated & SE & $t$-value & $P$ \\
\hline \multicolumn{5}{|l|}{ Overall density } \\
\hline (Intercept) & 6.9660 & 0.7755 & 8.983 & $<0.001$ \\
\hline Distance & -0.0196 & 0.0035 & -5.622 & $<0.001$ \\
\hline$P$. serotina density & 0.0000 & 0.0001 & 0.159 & 0.874 \\
\hline Tree stand type & -5.5270 & 0.8870 & -6.231 & $<0.001$ \\
\hline$P$. serotina density $\times$ tree stand type & 0.0141 & 0.0016 & 8.946 & $<0.001$ \\
\hline $\mathrm{AIC}=609.13$ & \multicolumn{4}{|c|}{ Log-likelihood $=-289.6$} \\
\hline \multicolumn{5}{|l|}{ Low shrubs (<0.5 m height) } \\
\hline (Intercept) & 6.6890 & 0.7946 & 8.418 & $<0.001$ \\
\hline Distance & -0.0187 & 0.0036 & -5.231 & $<0.001$ \\
\hline$P$. serotina density & 0.0000 & 0.0001 & 0.067 & 0.947 \\
\hline Tree stand type & -6.0250 & 0.9496 & -6.344 & $<0.001$ \\
\hline$P$. serotina density $\times$ tree stand type & 0.0148 & 0.0016 & 9.087 & $<0.001$ \\
\hline $\mathrm{AIC}=570.51$ & \multicolumn{4}{|c|}{ Log-likelihood $=-279.3$} \\
\hline \multicolumn{5}{|l|}{ Tall shrubs (>0.5 m height) } \\
\hline (Intercept) & 7.4732 & 0.9081 & 8.229 & $<0.001$ \\
\hline Distance & -0.0671 & 0.0095 & -7.082 & $<0.001$ \\
\hline$P$. serotina density & 0.0004 & 0.0001 & 3.107 & 0.002 \\
\hline $\mathrm{AIC}=336.08$ & \multicolumn{4}{|c|}{ Log-likelihood $=-164.0$} \\
\hline
\end{tabular}

\section{Discussion}

Our findings show that $C$. alternifolia is able to selfreproduce, because on five plots we found plants which were fruiting with small seedlings present. This species spreads successfully within Rogów Arboretum. Therefore, according to alien species classifications (Richardson et al. 2000; Pyšek et al. 2004), $C$. alternifolia is an invasive species, because it is able to reproduce and spread $>100 \mathrm{~m}$ over $<50$ years. However, this definition come from invasion ecology, and contrary to the definition provided by the IUCN, and does not take into account economical/environmental impact of an invasive species (Richardson et al. 2011). Surrounding forests could be able to host $C$. alternifolia, as they are also mostly plantations of coniferous or mixed tree stands in habitats of deciduous forests, despite the fact that they are dominated by a native species-Pinus sylvestris. However, C. alternifolia has not yet colonized natural plant communities in the neighborhood of the arboretum, and has not been seen at all outside the arboretum. In addition, C. alternifolia was not found in plots with mixed tree stands, especially those similar to surrounding forests. Therefore, according to the conservation biology definition, C. alternifolia may not be considered invasive, due to lack of confirmed impact on biodiversity. Nevertheless, its ability to spread due to its dispersal mode (zoochory) and ornamental value, resulting in its popularity in horticulture, and therefore increasing propagule pressure, are traits indicative of invasiveness (Pyšek et al. 2009; Rejmánek 2014). It is also possible that the $C$. alternifolia in Rogów represents the end of the 'lag phase' of biological invasion, as this last for an average of 131 years in cases of alien shrub species (Kowarik 1995). The main factor limiting the dispersal distance of $C$. alternifolia may be dispersion of seed sources from three scattered locations of only a few specimens; thus, the rate of dispersal distance may increase when more individuals start reproducing. Similarly, dispersal distance of $P$. serotina in Europe was more connected with planting intensity than with its dispersal traits (Starfinger et al. 2003; Vanhellemont et al. 2009).

The relationship between two alien species tested here could not be interpreted without taking into account other factors limiting their dispersal distance, e.g., distance from the propagule source (Deckers et al. 2005, 2008; Pairon et al. 2006). If C. alternifolia density was positively correlated with $P$. serotina density, it could be interpreted as the occurrence of one alien species facilitating secondary invasion, 
following the invasional meltdown concept (Simberloff and Von Holle 1999; Simberloff 2006). However, in the final model, density of P. serotina was not statistically significant. Densities of both species studied depended on distance from propagule source and tree stand type (Jagodziński et al. 2015), indicating that both species colonize similar plots; however, there were no interactions between them. This may show that the effect of invasional meltdown (Simberloff and Von Holle 1999; Simberloff 2006) is rather connected with tree stand species. Both $C$. alternifolia (this study) and P. serotina (Jagodziński et al. 2015), reached higher densities in plantations of coniferous species. Introduction of coniferous species, which are ecologically alien (according to potential natural vegetation) and in most cases geographically alien, is also an introduction of alien species, which resulted in changes of ecosystem properties (transformers sensu Richardson et al. 2000). Although we did not measure this transformation, there are a lot of studies describing how coniferous trees planted in habitats of broadleaved forests affect light conditions (e.g., Knight et al. 2008; Niinemets 2010; Mueller et al. 2016) or soil chemistry (e.g., Binkley and Valentine 1991; Reich et al. 2005; Mueller et al. 2012), which generally facilitated invasion of alien species (Obidziński and Symonides 2000; Chmura 2004, 2014; Zerbe and Wirth 2006; Paritsis and Aizen 2008).

Both species studied coexist in the arboretum, similar to their native range (Burns and Honkala 1990; Coladonato 1994). However, C. alternifolia naturally occurs only in the same habitats in which $P$. serotina also occurs, often under its canopy, and has a higher shade tolerance (Burns and Honkala 1990; Uchytil 1991; Coladonato 1994; Niinemets and Valladares 2006), which may explain its ecological success in plots invaded by $P$. serotina. Different shade tolerance of the species studied explains lack of significant influence of $P$. serotina on $C$. alternifolia density.

Although due to a high number of zero values, information about $C$. alternifolia ecological preferences for tree stands is misleading, and densities of $C$. alternifolia are statistically significantly higher in coniferous tree stands (Table 1). Together with higher frequency in coniferous tree stands (27/95 vs. 6/56), this may show that $C$. alternifolia occurs in coniferous tree stands rather than in broadleaved stands, similar to
P. serotina (Jagodziński et al. 2015). It also confirms observations of Zerbe and Wirth (2006), which found that tree stands of Pinus sylvestris host numerous alien species, including many invasive species. This case may also be considered as an invasional meltdownplantations of ecologically (and mostly also geographically) alien coniferous species facilitate dispersal distance of secondary invaders- $P$. serotina (Jagodziński et al. 2015) and C. alternifolia, and both species invade the most invasible stands. Tree stand invasibility is mainly connected with resource availability (Richardson et al. 2011), especially light (Knight et al. 2008). Moreover, habitats with high levels of resource availability are more colonized by both native, as well as alien species (Stohlgren et al. 2006). This theory may explain why both species studied colonized similar tree stands.

\section{Conclusions}

The study found that both alien species coming from the same geographical range and from similar plant communities (Burns and Honkala 1990) colonize similar tree stand types, despite the spatiotemporal difference in propagule pressure. Density of the secondary invader, C. alternifolia, depends on tree stand type, distance from the propagule source, and does not depend on density of invader-P. serotina. Density of $C$. alternifolia decreased with the increasing distance from the propagule source, and in broadleaved stands, it was lower than in coniferous stands. C. alternifolia has shown the same pattern of relationships between distance from the propagule source and tree stand type as for $P$. serotina in an earlier study (Jagodziński et al. 2015); habitats invaded by the primary invader seem to be also suitable for the secondary potential invader. The primary invader seems to neither facilitate nor limit the dispersal distance of $C$. alternifolia, as these two species differ in shade tolerance. C. alternifolia is able to spread up to $338 \mathrm{~m}$ from the introduction place within 39 years, which fulfills the criterion of invasibility, according to Richardson et al. (2000). The study also provided the first information about spontaneous spread of $C$. alternifolia, because earlier this species was noticed only as a casual escape from cultivation in Slovakia, and only in ruderal habitats (Medvecká et al. 2012). 
Acknowledgements We would like to thank for valuable help during field data collection to the following persons: Anna Barycza, Wojciech Borzyszkowski, Anna Gdula, Kamil Gęsikiewicz, Bartosz Kulawinek, Krzysztof Polański, Marta Reszczyńska, Marta Skwierczyńska, Bartłomiej Wojtkowiak, and Przemysław Zielonka. The study was financially supported by the Institute of Dendrology, Polish Academy of Sciences, Kórnik, Poland. We would like to thank Dr. Lee E. Frelich (The University of Minnesota Center for Forest Ecology, USA) for valuable suggestions and linguistic revision of the manuscript. We are grateful to the two anonymous reviewers for their commentary on an earlier draft of the manuscript.

Open Access This article is distributed under the terms of the Creative Commons Attribution 4.0 International License (http:// creativecommons.org/licenses/by/4.0/), which permits unrestricted use, distribution, and reproduction in any medium, provided you give appropriate credit to the original author(s) and the source, provide a link to the Creative Commons license, and indicate if changes were made.

\section{References}

Augusto L, Ranger J, Binkley D, Rothe A (2002) Impact of several common tree species of European temperate forests on soil fertility. Ann For Sci 59:233-253. doi:10.1051/ forest: 2002020

Binkley D, Giardina C (1998) Why do tree species affect soils? The warp and woof of tree-soil interactions. Biogeochemistry 42:89-106. doi:10.1023/A:1005948126251

Binkley D, Valentine D (1991) Fifty-year biogeochemical effects of green ash, white pine, and Norway spruce in a replicated experiment. For Ecol Manag 40:13-25. doi:10. 1023/A:1005948126251

Burns RM, Honkala BH (1990) Silvics of North America. U.S. Dept. of Agriculture, Forest Service, Washington

Castro-Díez P, Godoy O, Alonso A, Gallardo A, Saldaña A (2014) What explains variation in the impacts of exotic plant invasions on the nitrogen cycle? A meta-analysis. Ecol Lett 17:1-12. doi:10.1111/ele.12197

Chabrerie O, Verheyen K, Saguez R, Decocq G (2008) Disentangling relationships between habitat conditions, disturbance history, plant diversity, and American black cherry (Prunus serotina Ehrh.) invasion in a European temperate forest. Divers Distrib 14:204-212. doi:10.1111/j.14724642.2007.00453.x

Chmura D (2004) Penetration and naturalisation of invasive alien plant species (neophytes) in woodlands of the Silesian Upland (southern Poland). Nat Conserv 60:3-11

Chmura D (2014) Biology and ecology of an invasion of Impatiens parviflora $\mathrm{DC}$ in natural and semi-natural habitats. Wydawnictwo ATH, Bielsko-Biała

Coladonato M (1994) Cornus alternifolia. In: USDA Forest Service, Rocky Mountain Research Station, Fire Sciences Laboratory (ed) Fire effects information system. http:// www.fs.fed.us/database/feis/

Czępińska-Kamińska D, Janowska E, Konecka-Batley K (1991) Gleby Arboretum w Rogowie. Arboretum Rogów (typescript; in Polish)
Dauer JM, Chorover J, Chadwick OA, Oleksyn J, Tjoelker MG, Hobbie SE, Reich PB, Eissenstat DM (2007) Controls over leaf and litter calcium concentrations among temperate trees. Biogeochemistry 86:175-187. doi:10.1007/s10533007-9153-8

Davis MA (2003) Biotic globalization: does competition from introduced species threaten biodiversity? Bioscience 53:481-489. doi:10.1641/0006-3568(2003)053[0481:BG $\mathrm{DCFI}] 2.0 . \mathrm{CO} ; 2$

Deckers B, Verheyen K, Hermy M, Muys B (2005) Effects of landscape structure on the invasive spread of black cherry Prunus serotina in an agricultural landscape in Flanders, Belgium. Ecography 28:99-109. doi:10.1111/j.0906-7590. 2005.04054.x

Deckers B, Verheyen K, Vanhellemont M, Maddens E, Muys B, Hermy M (2008) Impact of avian frugivores on dispersal and recruitment of the invasive Prunus serotina in an agricultural landscape. Biol Invasions 10:717-727. doi:10. 1007/s10530-007-9164-3

Dickie IA, Oleksyn J, Reich PB, Karolewski P, Zytkowiak R, Jagodzinski AM, Turzanska E (2006) Soil modification by different tree species influences the extent of seedling ectomycorrhizal infection. Mycorrhiza 16:73-79. doi:10. 1007/s00572-005-0013-x

Ehrenfeld JG (2003) Effects of exotic plant invasions on soil nutrient cycling processes. Ecosystems 6:503-523. doi:10. 1007/s10021-002-0151-3

Gioria M, Osborne BA (2014) Resource competition in plant invasions: emerging patterns and research needs. Front Plant Sci 5:501. doi:10.3389/fpls.2014.00501

Gioria M, Dieterich B, Osborne BA (2011) Battle of the giants: primary and secondary invasions by large herbaceous species. Biol Environ 111B:177-193. doi:10.3318/BIOE. 2011.14

Gorchov DL, Trisel DE (2003) Competitive effects of the invasive shrub, Lonicera maackii (Rupr.) Herder (Caprifoliaceae), on the growth and survival of native tree seedlings. Plant Ecol 166:13-24. doi:10.1023/A:1023208 215796

Halarewicz A, Żołnierz L (2014) Changes in the understorey of mixed coniferous forest plant communities dominated by the American black cherry (Prunus serotina Ehrh.). For Ecol Manag 313:91-97. doi:10.1023/A:1023208215796

Hobbie SE, Reich PB, Oleksyn J, Ogdahl M, Zytkowiak R, Hale C, Karolewski P (2006) Tree species effects on decomposition and forest floor dynamics in a common garden. Ecology 87:2288-2297. doi:10.1890/0012-9658(2006)8 7[2288:TSEODA]2.0.CO;2

Hobbie SE, Ogdahl M, Chorover J, Chadwick OA, Oleksyn J, Zytkowiak R, Reich PB (2007) Tree species effects on soil organic matter dynamics: the role of soil cation composition. Ecosystems 10:999-1018. doi:10.1007/s10021-0079073-4

Hobbie SE, Oleksyn J, Eissenstat DM, Reich PB (2010) Fine root decomposition rates do not mirror those of leaf litter among temperate tree species. Oecologia 162:505-513. doi:10.1007/s00442-009-1479-6

Jagodziński AM, Banaszczak P (2010) Stem volume and aboveground woody biomass in Noble fir (Abies procera Rehder) stands in Rogów Arboretum (Poland). Acta Sci Pol Silv Colendar Rat Ind Lignar 9:9-24 
Jagodziński AM, Skorupski M, Kasprowicz M, Wojterska M, Dobies T, Kałucka I, Sławska M, Wierzbicka A, Łabędzki A, Oleszyńska-Niżniowska J, Nowiński M, Małek S, Karolewski P, Oleksyn J, Banaszczak P (2011) Biodiversity of Greek fir (Abies cephalonica Loudon) experimental stands in Rogów Arboretum (Poland). Acta Sci Pol Silv Colendar Rat Ind Lignar 10:5-15

Jagodziński AM, Dyderski MK, Rawlik M, Banaszczak P (2015) Plantation of coniferous trees modifies risk and size of Padus serotina (Ehrh.) Borkh. invasion-Evidence from a Rogów Arboretum case study. For Ecol Manag 357:84-94. doi:10.1016/j.foreco.2015.08.011

Jo I, Fridley JD, Frank DA (2015) Linking above- and belowground resource use strategies for native and invasive species of temperate deciduous forests. Biol Invasions 17:1545-1554. doi:10.1007/s10530-014-0814-y

Kałucka I, Jagodziński AM, Skorupski M, Kasprowicz M, Wojterska M, Dobies T, Sławska M, Wierzbicka A, Łabędzki A, Nowiński M, Małek S, Banaszczak P, Karolewski P, Oleksyn J (2013) Biodiversity of Balcan pine (Pinus peuce Griseb.) experimental stands in the Rogów Arboretum (Poland). Folia For Pol Ser. A 55:181-189

Kasprowicz M, Jagodziński AM, Skorupski M, Wojterska M, Dobies T, Kałucka I, Sławska M, Wierzbicka A, Łabędzki A, Nowiński M, Karolewski P, Oleksyn J, Banaszczak P, Małek S (2011) The list of plants, fungi and invertebrates of noble fir (Abies procera Rehder) experimental stands in Rogów Arboretum (Poland). Acta Sci Pol Silv Colendar Rat Ind Lignar 10:17-27

Kawaletz H, Mölder I, Annighöfer P, Terwei A, Zerbe S, Ammer C (2014) Back to the roots: how do seedlings of native tree species react to the competition by exotic species? Ann For Sci 71:337-347. doi:10.1007/s13595-0130347-z

Knight KS, Oleksyn J, Jagodzinski AM, Reich PB, Kasprowicz M (2008) Overstorey tree species regulate colonization by native and exotic plants: a source of positive relationships between understorey diversity and invasibility. Divers Distrib 14:666-675. doi:10.1111/j.1472-4642.2008.00468. $\mathrm{X}$

Kowarik I (1995) Time lags in biological invasions with regard to the success and failure of alien species. In: Pyšek P, Prach K, Rejmánek M, Wade M (eds) Plant invasionsgeneral aspects and special problems. SPB Academic Publishing, Amsterdam, pp 15-38

Křivánek M, Pyšek P, Jarošík V (2006) Planting history and propagule pressure as predictors of invasion by woody species in a temperate region. Conserv Biol 20:1487-1498. doi:10.1111/j.1523-1739.2006.00477.x

Lockwood JL, Cassey P, Blackburn T (2005) The role of propagule pressure in explaining species invasions. Trends Ecol Evol 20:223-228. doi:10.1016/j.tree.2005.02.004

Lonsdale WM (1999) Global patterns of plant invasions and the concept of invasibility. Ecology 80:1522-1536. doi:10. 1890/0012-9658(1999)080[1522:GPOPIA]2.0.CO;2

Lövei GL (1997) Biodiversity: global change through invasion. Nature 388:627-628

Mangla S, Sheley RL, James JJ, Radosevich SR (2011) Intra and interspecific competition among invasive and native species during early stages of plant growth. Plant Ecol 212:531-542. doi:10.1007/s11258-011-9909-Z
McShane RR, Auerbach DA, Friedman JM, Auble GT, Shafroth PB, Merigliano MF, Scott ML, Poff NL (2015) Distribution of invasive and native riparian woody plants across the western USA in relation to climate, river flow, floodplain geometry and patterns of introduction. Ecography 38:1254-1265. doi:10.1111/ecog.01285

Medvecká J, Kliment J, Majekova J, Halada L, Zaliberova M, Gojdičová E, Ferakova V, Jarolimek I (2012) Inventory of the alien flora of Slovakia. Preslia 84:257-309

Menge DNL, Chazdon RL (2016) Higher survival drives the success of nitrogen-fixing trees through succession in Costa Rican rainforests. New Phytol 209:965-977. doi:10. 1111/nph.13734

Mony C, Koschnick TJ, Haller WT, Muller S (2007) Competition between two invasive Hydrocharitaceae (Hydrilla verticillata (L.f.) (Royle) and Egeria densa (Planch)) as influenced by sediment fertility and season. Aquat Bot 86:236-242. doi:10.1016/j.aquabot.2006.11.007

Mueller KE, Eissenstat DM, Hobbie SE, Oleksyn J, Jagodzinski AM, Reich PB, Chadwick OA, Chorover J (2012) Tree species effects on coupled cycles of carbon, nitrogen, and acidity in mineral soils at a common garden experiment. Biogeochemistry 111:601-614. doi:10.1007/s10533-0119695-7

Mueller KE, Hobbie SE, Chorover J, Reich PB, Eisenhauer N, Castellano MJ, Chadwick OA, Dobies T, Hale CM, Jagodziński AM, Kałucka I, Kieliszewska-Rokicka B, Modrzyński J, Rożen A, Skorupski M, Sobczyk Ł, Stasińska M, Trocha LK, Weiner J, Wierzbicka A, Oleksyn J (2015) Effects of litter traits, soil biota, and soil chemistry on soil carbon stocks at a common garden with 14 tree species. Biogeochemistry 123:313-327. doi:10.1007/ s10533-015-0083-6

Mueller KE, Eisenhauer N, Reich PB, Hobbie SE, Chadwick OA, Chorover J, Dobies T, Hale CM, Jagodziński AM, Kałucka I, Kasprowicz M, Kieliszewska-Rokicka B, Modrzyński J, Rożen A, Skorupski M, Sobczyk Ł, Stasińska M, Trocha LK, Weiner J, Wierzbicka A, Oleksyn J (2016) Light, earthworms, and soil resources as predictors of diversity of 10 soil invertebrate groups across monocultures of 14 tree species. Soil Biol Biochem 92:184-198. doi:10.1016/j.soilbio.2015.10.010

Niinemets $\ddot{U}$ (2010) A review of light interception in plant stands from leaf to canopy in different plant functional types and in species with varying shade tolerance. Ecol Res 25:693-714. doi:10.1007/s11284-010-0712-4

Niinemets Ü, Valladares F (2006) Tolerance to shade, drought, and waterlogging of temperate Northern Hemisphere trees and shrubs. Ecol Monogr 76:521-547. doi:10.1890/00129615(2006)076[0521:TTSDAW]2.0.CO;2

O'Hara RB, Kotze DJ (2010) Do not log-transform count data. Methods Ecol Evol 1:118-122. doi:10.1111/j.2041-210X. 2010.00021.x

Obidziński T, Symonides E (2000) The influence of the groundlayer structure on the invasion of small balsam (Impatiens parviflora DC.) to natural and degraded forests. Acta Soc Bot Pol 69:311-318. doi:10.5586/asbp.2000.041

Pairon M, Jonard M, Jacquemart A-L (2006) Modeling seed dispersal of black cherry, an invasive forest tree: how microsatellites may help? Can J For Res 36:1385-1394. doi:10.1139/x06-018 
Paritsis J, Aizen MA (2008) Effects of exotic conifer plantations on the biodiversity of understory plants, epigeal beetles and birds in Nothofagus dombeyi forests. For Ecol Manag 255:1575-1583. doi:10.1016/j.foreco.2007.11.015

Pyšek P, Richardson DM, Rejmánek M, Webster GL, Williamson M, Kirschner J (2004) Alien plants in checklists and floras: towards better communication between taxonomists and ecologists. Taxon 53:131-143. doi:10.2307/ 4135498

Pyšek P, Křivánek M, Jarošík V (2009) Planting intensity, residence time, and species traits determine invasion success of alien woody species. Ecology 90:2734-2744. doi:10. 1890/08-0857.1

Pyšek P, Manceur AM, Alba C, McGregor KF, Pergl J, Štajerová K, Chytrý M, Danihelka J, Kartesz J, Klimešová J, Lučanová M, Moravcová L, Nishino M, Sádlo J, Suda J, Tichý L, Kühn I (2015) Naturalization of central European plants in North America: species traits, habitats, propagule pressure, residence time. Ecology 96:762-774. doi:10. $1890 / 14-1005.1$

R Core Team (2015) R: a language and environment for statistical computing. R Foundation for Statistical Computing, Vienna

Reich PB, Oleksyn J, Modrzynski J, Mrozinski P, Hobbie SE, Eissenstat DM, Chorover J, Chadwick OA, Hale CM, Tjoelker MG (2005) Linking litter calcium, earthworms and soil properties: a common garden test with 14 tree species. Ecol Lett 8:811-818. doi:10.1111/j.1461-0248. 2005.00779.x

Rejmánek M (2014) Invasive trees and shrubs: where do they come from and what we should expect in the future? Biol Invasions 16:483-498. doi:10.1007/s10530-013-0603-z

Rice SK, Westerman B, Federici R (2004) Impacts of the exotic, nitrogen-fixing black locust (Robinia pseudoacacia) on nitrogen-cycling in a pine-oak ecosystem. Plant Ecol 174:97-107. doi:10.1023/B:VEGE.0000046049.21900.5a

Richardson DM, Pyšek P (2006) Plant invasions: merging the concepts of species invasiveness and community invasibility. Prog Phys Geogr 30:409-431. doi:10.1191/ 0309133306pp490pr

Richardson DM, Rejmánek M (2011) Trees and shrubs as invasive alien species - a global review. Divers Distrib 17:788-809. doi:10.1111/j.1472-4642.2011.00782.x

Richardson DM, Pyšek P, Rejmánek M, Barbour MG, Panetta FD, West CJ (2000) Naturalization and invasion of alien plants: concepts and definitions. Divers Distrib 6:93-107. doi:10.1046/j.1472-4642.2000.00083.x

Richardson DM, Pyšek P, Carlton T (2011) A compendium of essential concepts and terminology in invasion ecology. In: Richardson DM (ed) Fifty years of invasion ecology: the legacy of Charles Elton. Blackwell Publishing, Chirchester, pp 409-420

Riepšas E, Straigyté L (2008) Invasiveness and ecological effects of red oak (Quercus rubra L.) in Lithuanian forests. Balt For 14:122-130

Robakowski P, Bielinis E (2011) Competition between sessile oak (Quercus petraea) and black cherry (Padus serotina): dynamics of seedlings growth. Pol J Ecol 59:297-306

Rodríguez-Echeverría S, Afonso C, Correia M, Lorenzo P, Roiloa SR (2013) The effect of soil legacy on competition and invasion by Acacia dealbata link. Plant Ecol 214:1139-1146. doi:10.1007/s11258-013-0238-2

Saccone P, Pagès J-P, Girel J, Brun J-J, Michalet R (2010) Acer negundo invasion along a successional gradient: early direct facilitation by native pioneers and late indirect facilitation by conspecifics. New Phytol 187:831-842. doi:10.1111/j.1469-8137.2010.03289.x

Sanderson L, Antunes P (2013) The exotic invasive plant Vincetoxicum rossicum is a strong competitor even outside its current realized climatic temperature range. NeoBiota 16:1-15. doi:10.3897/neobiota.16.4012

Simberloff D (2006) Invasional meltdown 6 years later: important phenomenon, unfortunate metaphor, or both? Ecol Lett 9:912-919. doi:10.1111/j.1461-0248.2006. 00939.x

Simberloff D, Von Holle B (1999) Positive interactions of nonindigenous species: invasional meltdown? Biol Invasions 1:21-32. doi:10.1023/A:1010086329619

Sinclair JS, Arnott SE (2015) Strength in size not numbers: propagule size more important than number in sexually reproducing populations. Biol Invasions 18:497-505. doi:10.1007/s10530-015-1022-0

Skorupski M, Jagodzinski AM, Kałucka I, Kasprowicz M, Wojterska M, Dobies T, Sławska M, Wierzbicka A, Łabędzki A, Oleszyńska-Niżniowska J, Nowiński M, Małek S, Karolewski P, Oleksyn J, Banaszczak P (2011) Plants, fungi and invertebrates of Grand Fir [Abies grandis (Douglas ex D. Don) Lindl.] experimental stands in Rogów Arboretum (Poland). Acta Sci Pol Silv Colendar Rat Ind Lignar 10:39-49

Starfinger U, Kowarik I, Rode M, Schepker H (2003) From desirable ornamental plant to pest to accepted addition to the flora?- the perception of an alien tree species through the centuries. Biol Invasions 5:323-335. doi:10.1023/B: BINV.0000005573.14800.07

Stohlgren TJ, Rejmánek M (2014) No universal scale-dependent impacts of invasive species on native plant species richness. Biol Lett 10:20130939. doi:10.1098/rsbl.2013.0939

Stohlgren T, Jarnevich C, Chong GW, Evangelista PH (2006) Scale and plant invasions: a theory of biotic acceptance. Preslia 78:405-426

Terwei A, Zerbe S, Zeileis A, Annighöfer P, Kawaletz H, Mölder I, Ammer C (2013) Which are the factors controlling tree seedling establishment in North Italian floodplain forests invaded by non-native tree species? For Ecol Manag 304:192-203. doi:10.1016/j.foreco.2013.05.003

Trocha LK, Kałucka I, Stasińska M, Nowak W, Dabert M, Leski T, Rudawska M, Oleksyn J (2012) Ectomycorrhizal fungal communities of native and non-native Pinus and Quercus species in a common garden of 35-year-old trees. Mycorrhiza 22:121-134. doi:10.1007/s00572-011-0387-x

Uchytil RJ (1991) Prunus serotina. In: USDA Forest Service, Rocky Mountain Research Station, Fire Sciences Laboratory (ed) Fire Effects information system. http://www.fs. fed.us/database/feis/plants/tree/pruser/all.html

Vanhellemont M, Verheyen K, Keersmaeker L, Vandekerkhove K, Hermy M (2009) Does Prunus serotina act as an aggressive invader in areas with a low propagule pressure? Biol Invasions 11:1451-1462. doi:10.1007/s10530-0089353-8 
Venables WN, Ripley BD (2002) Modern applied statistics with S. Springer, New York

Vitousek PM (1990) Biological invasions and ecosystem processes: towards an integration of population biology and ecosystem studies. Oikos 57:7-13. doi:10.1007/978-14612-4018-1_17

Withington JM, Reich PB, Oleksyn J, Eissenstat DM (2006) Comparisons of structure and life span in roots and leaves among temperate trees. Ecol Monogr 76:381-397. doi:10. 1890/0012-9615(2006)076[0381:COSALS]2.0.CO;2

Wojterska M, Jagodziński AM, Skorupski M, Kasprowicz M, Dobies T, Sławska M, Wierzbicka A, Łabędzki A, Nowiński M, Małek S, Banaszczak P, Karolewski P, Oleksyn J
(2012) Species diversity related to red maple (Acer rubrum L.) occurred on experimental stands in Rogów Arboretum (Poland). Folia For Pol Ser A 54:233-240

Zerbe S, Wirth P (2006) Non-indigenous plant species and their ecological range in Central European pine (Pinus sylvestris L.) forests. Ann For Sci 63:189-203. doi:10.1051/forest: 2005111

Żywiec M, Holeksa J, Wesołowska M, Szewczyk J, ZwijaczKozica T, Kapusta P (2013) Sorbus aucuparia regeneration in a coarse-grained spruce forest - a landscape scale. J Veg Sci 24:735-743. doi:10.1111/j.1654-1103.2012.01493.x 